\title{
Correction to: Effect of lumbopelvic control on landing mechanics and lower extremity muscles' activities in female professional athletes: implications for injury prevention
}

\author{
Paria Fadaei Dehcheshmeh ${ }^{1}$ (B), Farzaneh Gandomi ${ }^{{ }^{*}}$ (1) and Nicola Mafulli ${ }^{2,3,4,5}$ (1)
}

\section{Correction to: BMC Sports Sci Med Rehabil (2021) 13:101 https://doi.org/10.1186/s13102-021-00331-y}

Following publication of the original article [1], the authors identified an error in the author name of Paria Fadaei Dehcheshmeh.

The incorrect author name is: Paria Fadari Dehcheshmeh. The correct author name is: Paria Fadaei Dehcheshmeh.

\author{
Reference \\ 1. Fadaei Dehcheshmeh P, Gandomi F, Maffulli N. Effect of lumbopelvic \\ control on landing mechanics and lower extremity muscles' activi- \\ ties in female professional athletes: implications for injury prevention. \\ BMC Sports Sci Med Rehabil. 2021;13:101. https://doi.org/10.1186/ \\ s13102-021-00331-y.
}

\section{Publisher's Note}

Springer Nature remains neutral with regard to jurisdictional claims in published maps and institutional affiliations.

The author group has been updated above and the original article [1] has been corrected.

\begin{abstract}
Author details
${ }^{1}$ Department of Sport Injuries and Corrective Exercises, Sports Sciences Faculty, Razi University, Kermanshah, Iran. ${ }^{2}$ Department of Musculoskeletal Disorders, Via Salvador Allende, 43, 84081 Baronissi, Italy. ${ }^{3}$ Clinica Ortopedica, Ospedale San Giovanni di Dio E Ruggi D'Aragona, Largo Città di Ippocrate, 84131 Salerno, Italy. ${ }^{4}$ Barts and the London School of Medicine and Dentistry, Centre for Sports and Exercise Medicine, Mile End Hospital, Queen Mary University of London, 275 Bancroft Road, London E14DG, England. ${ }^{5}$ School of Pharmacy and Bioengineering, Faculty of Medicine, Guy Hilton Research Centre, Keele University, Thornburrow Drive, Hartshill, Stoke-on-Trent ST4 7QB, England.
\end{abstract}

Published online: 09 September 2021

The original article can be found online at https://doi.org/10.1186/s13102021-00331-y.

*Correspondence: gandomi777@gmail.com

1 Department of Sport Injuries and Corrective Exercises, Sports Sciences Faculty, Razi University, Kermanshah, Iran

Full list of author information is available at the end of the article

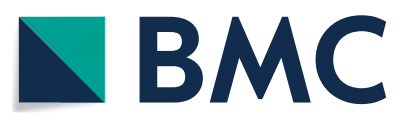

(c) The Author(s) 2021. Open Access This article is licensed under a Creative Commons Attribution 4.0 International License, which permits use, sharing, adaptation, distribution and reproduction in any medium or format, as long as you give appropriate credit to the original author(s) and the source, provide a link to the Creative Commons licence, and indicate if changes were made. The images or other third party material in this article are included in the article's Creative Commons licence, unless indicated otherwise in a credit line to the material. If material is not included in the article's Creative Commons licence and your intended use is not permitted by statutory regulation or exceeds the permitted use, you will need to obtain permission directly from the copyright holder. To view a copy of this licence, visit http://creativecommons.org/licenses/by/4.0/. The Creative Commons Public Domain Dedication waiver (http://creativecommons.org/publicdomain/zero/1.0/) applies to the data made available in this article, unless otherwise stated in a credit line to the data. 